\title{
Enhanced Methanol Oxidation on Nanoporous Nickel Phosphate Modified Platinum Electrode in Alkaline Solution
}

\author{
Ahmed. H. Touny ${ }^{1,3, *}$, Mahmoud. M. Saleh ${ }^{1,2, *}$ \\ ${ }^{1}$ Department of Chemistry, College of Science, King Faisal University, Al-Hassa, Saudi Arabia \\ ${ }^{2}$ Department of Chemistry, Faculty of Science, Cairo University, Cairo, Egypt \\ ${ }^{3}$ Department of Chemistry, Faculty of Science, Helwan University, Helwan, Egypt \\ *E-mail: aahamed@kfu.edu.sa, atouny@yahoo.com, mmsaleh@kfu.edu.sa \\ mahmoudsaleh90@yahoo.com
}

doi: $10.20964 / 2018.01 .55$

Received: 26 July 2017 / Accepted: 11 October 2017 / Published: 16 December 2017

The theme of this paper is to enhance the methanol oxidation via nanoporous nickel phosphate (nano$\mathrm{NiPh})$ modified platinum $(\mathrm{Pt})$ electrode in alkaline solution. Nickel phosphate material is synthesized by a simple reflux-based method and characterized by Scanning electron Microscope (SEM), tunneling electron microscopy (TEM), FT-IR absorption spectroscopy and X-ray diffraction (XRD). The NiPh has the chemical structure of $\mathrm{Ni}_{3}\left(\mathrm{PO}_{4}\right)_{2} .8 \mathrm{H}_{2} \mathrm{O}$ with nanoporous features and monoclinic crystallographic form. Nickel phosphate particles produced in agglomerated particles with a crystal growth along one direction (c-direction)) to form rods or whisker-shape structures. The surface of the rods formed with nanoporous structure (pore diameter $\sim 30 \mathrm{~nm}$ ). These pores are distributed throughout the surface of the $\mathrm{NiPh}$ particles. Platinum modified with nano- $\mathrm{NiPh}$ (nano-NiPh/Pt) demonstrates enhanced methanol oxidation from alkaline solution. The peak of direct current (forward sweep), the onset potential and the ratio of the direct to indirect currents have demonstrated the enhancement of the $\mathrm{MeOH}$ oxidation at the nano- $\mathrm{NiPh} / \mathrm{Pt}$ compared to that obtained with unmodified Pt electrode.

Keywords: Methanol, Pt, Nickel phosphate, fuel cell, nanoporous

\section{FULL TEXT}

(C) 2018 The Authors. Published by ESG (www.electrochemsci.org). This article is an open access article distributed under the terms and conditions of the Creative Commons Attribution license (http://creativecommons.org/licenses/by/4.0/). 